\title{
Interaksi Antar Dua Komunitas Agama (Islam-Kristen) Pasca Konflik di Desa Latta Kota Ambon
}

\author{
Alce Albartin Sapulette \\ Institut Agama Kristen Negeri Ambon \\ sapulettealce4@gmail.com
}

\begin{abstract}
Latta Village is one of the villages besides Wayame Village which did not experience the impact of the Maluku conflict in 1999, even though the people were multi-religious (Islam and Christian). The people of Latta Village remain united and maintain the common life order between Islam and Christianity that has been fostered from the beginning. Relationships or social relations remain well intertwined with one another. Research has been conducted on the interaction between two religious communities (Islam-Christians) post-conflict in Latta Village, Ambon City. This study aims to describe the social interactions that occur in the community using a qualitative approach. Based on the results of the study, it was found that there was an interaction relationship that remained intertwined in the lives of the people of Latta Village before and after the conflict. The relationship occurred because of good contact and communication between the Islamic community and the Christian community, and also because of the intervention of the Village Head, Imams, Priests and the community as a whole. Therefore, it can be concluded that the interaction relationships must remain maintained in order to create a life of a peaceful and harmonious society.
\end{abstract}

Keywords: social interaction, religious community,conflict

\section{Pengantar}

Mendiami sebuah wilayah atau lingkungan dalam jangka waktu yang cukup panjang membuat seseorang berperilaku dan bertindak sesuai dengan kondisi lingkungan sosial dimana orang itu berada. Lingkungan sosial yang didiami dalam jangka waktu cukup lama akan menimbulkan sebuah proses interaksi yang mengarah kepada proses pembentukkan karakter seseorang. Ini berarti bahwa lingkungan merupakan wadah atau tempat seseorang membentuk karakter, termasuk didalamnya karakter yang berhubungan dengan emosi keagamaan. Hal ini sama dengan apa yang disampaikan oleh Ross dan Gloria Kinsler tentang Analogi Gelas sampanye. Hal ini dimaksudkan bahwa dengan melihat gelas sampanye maka, seseorang diajak untuk menyadari posisi orang lain dalam realita kehidupan sosialnya. (Ross dan Gloria Kinsler,1996)

Untuk mengetahui karakter seseorang maka seseorang harus menjadi tujuan utama dari perasaanperasaan serta hasratnya yang nyata dalam sikap dan perilaku, demikian halnya untuk mengetahui karakter beragama seseorang maka harus melihat bagaimana sikap dan perilakunya terhadap penganut agama lain didalam lingkungan sosialnya. Dalam pandangan seseorang tentang agamanya dan agama orang lain ditemui berbagai fenomena konsep pikir yang mengkleim bahwa kebe-naran absolut ada pada kelompok agamanya sehingga orang lain yang ada di luar agamanya tidak dapat selamat dan kalau ingin selamat maka harus beralih memeluk agama yang sama. Dengan demikian maka, konsep ini mengarah kepada karakteristik masing-masing agama untuk membangun identitas dan ideologinya masing-masing.

Identitas merupakan sumber makna dan pengalaman manusia. Dalam hal ini identitas sebagai sesuatu yang mengacu kepada aktor sosial (orang yang bertindak) yang dipahami sebagai proses merekonstruksi makna atas dasar suatu atribut kultural atau satu kumpulan atribut sosial yang saling berhubungan.(Manuael Castells,2003) .Ada dua bentuk identitas yaitu identitas individu dan identitas pluralitas. Sebuah pluralitas identitas bersumber dari tekanan dan kontradiksi dalam representasi diri dan aksi sosial. Identitas membedakan apa yang tradisional, yang disebut sebagai identitas peran sosial dan serangkaian peran. Ada perbedaan antara identitas dan peran. Identitas lebih menekankan kepada makna atau tujuan tindakan yang dibangun melalui proses individualisasi, sedangkan peranan lebih menunjukkan kepada label dalam diri seseorang.

Pada dasarnya sebuah identitas merupakan hasil dari dikonstruksikan/diciptakan/dibangun yang 
bersumber pada macam-macam sejarah, geografi, biologis, memori kolektif, aparatus kekuasaan dan penyataan agamawi, dll. Dalam pembentukkan identitas, individu, kelompok sosial, dan masyarakat harus melihat pada seluruh materi-materi ini, mengatur kembali mak-nanya sesuai dengan determinasi sosial dan produk budaya yang berakar pada struktur sosial masyarakat dan dalam kerangka waktu dan tempat. Hal ini mengarah kepada kehidupan sosial kemasyarakatan yang terjadi dalam kehi-dupan masyarakat beragama di Maluku.

Fenomena yang sangat menarik dalam kehidupan beragama masyarakat Maluku merupakan hal unik yang perlu ditelusuri. Historis kehidupan masyarakat di Desa Latta sebelum konflik, saat konflik ber-darah 19 Januari 1999 sampai pasca konflik hidup berdampingan secara damai antara komunitas Islam maupun Kristen. Singkat, tragedi kemanusiaan yang terjadi diakibatkan karena kesalah pahaman masyarakat beragama di Maluku (Islam-Kristen) sehingga terjadi pertikaian diantara kedua komunitas beragama itu. Hal itu kemudian berdampak pada beberapa kepala keluarga (KK) yang beragama Islam di Desa Latta untuk keluar/meninggalkan Desa Latta karena takut (tidak ada konflik antar komunitas Islam-Kristen), tetapi sebagian besar kepala keluarga (KK) dari komunitas Islam masih tetap tinggal menetap. Setelah konflik, ada upaya dari pemerintah desa maupun para tokoh agama dan masyarakat untuk membangun satu hubungan ke arah yang lebih baik dengan mengambil jalan keluar membangun kekerabatan bukan lagi pada satu komunitas tetapi sudah menjadi dua komunitas (Islam-Kristen), dengan jalan mengembalikan beberapa kepala keluarga (KK) yang beragama Islam tersebut untuk kembali ke Desa Latta. Tujuannya adalah memperbaiki dan memperkokoh hubungan kekeluargaan yang terganggu/ternodai akibat konflik berdarah tahun 1999. Hal ini yang menjadi dasar dari proses penelitian yang akan dilakukan dan nantinya akan memberikan kontribusi pikir yang baru dalam mempererat kembali hubungan keberagamaan (Islam-Kristen) di Maluku.

\section{A. Perumusan Masalah}

Dari gambaran latar belakang diatas, maka perumusan masalahnya yaitu: Bagaimana interaksi sosial yang terjadi dalam komunitas beragama (Islam-Kristen) pasca konflik di Desa Latta Kota Ambon.

\section{B. Tujuan Penelitian}

Tujuan Penelitian ini yaitu: Mengkaji interaksi sosial yang terjadi dalam komunitas beragama (IslamKristen) pasca konflik di Desa Latta, Kota Ambon

\section{Metode}

Penelitian ini menggunakan metode penelitian deskriptif kualitatif. Sebagaimana dikemukakan oleh Bloog dan Taylor dalam Moleong (1989) yang mengatakan bahwa penelitian ini diartikan sebagai suatu metode penelitian yang menghasilkan data deskriptif berupa kata-kata yang tertulis dan lisan dari orang-orang dan tindakan-tindakanya yang akan diamati, dan tujuannya adalah untuk menyumbangkan pengetahuan secara mendalam mengenai objek masalah yang dikaji dalam penelitian tersebut.

Penelitian ini dilakukan di Desa Latta Kota Ambon. Hal ini dengan pertimbangan bahwa Desa ini merupakan salah satu desa yang terkena konflik namun hubungan interaksi antar masyarakat yang homogen baik dari segi agama maupun suku tetap terjalin erat. Setelah melakukan pengamatan di lapangan penulis mencoba untuk mengelompokkan data penelitian menjadi dua bagian, pertama data primer yaitu jenis data ini dikumpulkan secara langsung ketika melakukan wawancara mendalam terhadap beberapa informan kunci dengan masyarakat desa Latta dan data sekunder yaitu penulis juga memanfaatkan sumber data sekunder khususnya data-data penduduk/monografi desa. Sehingga gambaran tentang desa bisa dilihat dari monografi desa yang ada.

Teknik pengumpulan data dila-kukan dengan menggunakan 3 pendekatan yaitu (1) observasi langsung dilakukan dengan melihat aktifitas keseharian para informan dalam masyarakat, (2) wawancara mendalam dilakukan terhadap informan dengan mengunakan instrumen penelitian berupa pedoman wawancara. Instrumen penelitian ini digunakan agar apa yang ditanyakan dalam wawancara tidak keluar dari tujuan penelitian. Instrumen ini tidak bersifat kaku (fleksible) sehingga memungkinkan informan berceritera lebih mendalam tentang pertanyaan yang diajukan, (3) dokumentasi dilakukan dengan cara mengumpulkan data berupa arsip dan tulisan yang ada hubungannya dengan masalah penelitian ataupun dari sumber data lain yang relevan.

Teknik analisa data yang digunakan dalam penelitian ini dengan model analisis interaktif, yaitu analisis yang bergerak dalam tiga komponen besar 
adalah; Reduksi data (data reduction), sajian data (data display), penarikan kesimpulan dan verifikasi.

Pertama; reduksi data meliputi proses pemilihan, pemusatan perhatian, penyederhanaan, pengabstrakan dan transformasi data mentah yang muncul dari catatan-catatan tertulis di lapangan maupun hasil wawancara yang ada. Reduksi data ini merupakan bentuk analisis yang menajamkan, menggolongkan, mengarahkan, dan membuang data yang tidak sesuai, serta mengorganisasikan data hingga kesimpulan akhir yang dapat diferivikasi. Kedua; penyajian data (display data) merupakan proses penyajian data yang dilakukan untuk menyusun informasi yang terkumpul dan memungkinkan adanya upaya pena-rikan kesimpulan. Hal ini penting untuk dapat memahami apa yang sedang terjadi dan apa yang di lakukan sehingga anaslis yang dihasilkan berdasarkan atas pemahaman yang didapat dari penyajian-penyajian data tersebut. Ketiga; penarikan kesimpulan adalah proses yang dilakukan untuk mengetahui arti dari semua data yang dikumpulkan mulai dari awal sampai akhir penelitian.

\section{Hasil}

\section{Gambaran Umum Lokasi}

Latta adalah salah satu desa yang berada di Kota Ambon. Desa yang berpenduduk kurang lebih 1.725 orang adalah desa yang berpenduduk beragama Kristen dan Muslim. Posisi desa Latta di apit oleh desa-desa yang beragama Kristen Protestan namun dalam kesehariannya warga desa berinteraksi dengan baik dan saling menciptakan kerukunanan antar umat beragama dan pola hidup masyarakat untuk menjadi satu selalu dilakukan.

Desa Latta dalam perkembangannya cukup baik dan maju berposisi di daerah perkotaan dan merupakan pusat pelaksanaan ekonomi dari Kota Ambon sebagai desa yang harus berkembang sesuai dengan kemajuan ilmu pengetahuan dan tingkat pemenuhan ekonomi masyarakat yang baik. Dengan infrastruktur desa yang memadai serta faktor keterbukaan yang dialami dewasa ini, maka komunikasi antar sesama warga dan desa dengan desa lain selalu dilakukan dengan baik. Kemajuan ilmu pengetahuan dan teknologi memberikan ruang untuk desa ini dapat menerima akses informasi yang lebih baik dan berguna bagi masyarakat, sehingga berbagai issue sosial maupun ekonomi dapat dipahami oleh masyarakat setempat. Kondisi desa dewasa ini sangatlah baik dalam pola hidup bermasyarakat baik dalam desa maupun antar desa, olehnya itu kekerabatan itu bukanlah diciptakan karena pengaruh sosial seperti keterpurukan nilai budaya dan agama akan tetapi kehidupan masyarakat di desa Latta sudah tercipta sejak dulu, dimana kebersamaan hidup mereka antara desa sangatlah baik.

Kerukunan antar warga desa dan sesama umat beragama ini diciptakan dengan dalam bentuk kerjasama dan kehidupan sosial lainnya seperti bakti desa, bakti gereja atau mesjid dan bahkan dalam kegiatan-kegiatan keagamaan lainnya dilakukan dengan bersama. Olehnya itu ketika konflik horisontal yang terjadi Maluku desa Latta dengan tenangnya menjalankan kehidupan masyarakatnya dengan baik dan tenang tanpa ada gangguan dari manapun. Ketahanan nilai-nilai budaya dan sosial kemasyarakatan adalah ciri pokok dalam menciptakan kebersamaan antara sesama warga di desa maupun antar desa.

Desa Latta berada pada Kecamatan Teluk Ambon Baguala Kota Ambon Propinsi Maluku. Desa ini secara georgrafis berada pada batas-batas sebagai berikut :
a. Sebelah Timur berbatasan dengan Teluk Ambon
b. Sebelah Barat berbatasan dengan Negeri Halong
c. Sebelah Utara berbatasan dengan Negeri Halong
d. Sebelah Selatan berbatasan dengan Negeri Halong
Desa ini diapit oleh empat desa yang beragama Kristen Protestan. Jangkauan antara Ibu Kota Ambon dengan Desa Latta sekitar 20-25 menit dengan meng-gunakan angkutan darat. Berdasar-kan kondisi iklim di Maluku, maka Desa Latta termasuk kategori iklim laut tropis, dengan keadaan musim kemarau hampir sepanjang tahun, sesuai data tersebut di atas maka dapat disimpulkan bahwa musim timur yang dikenal dengan musim kemarau berlangsung dari bulan Mei-September, musim barat (hujan) berlangsung dari bulan Oktober-April. Selain kedua musim tersebut ada juga dikenal dengan musim pancaroba atau musim peralihan yang terjadi diantara kedua musim yang berlangsung an-tara bulan April dan bulan Oktober.

Posisi Desa Latta yang berada di tengahtengah Kota Ambon dan merupakan bentuk desa adat yang masih berbaur dengan berbagai kemajuan ilmu pengetahuan dan teknologi dan bahkan tingkat 
pendi-dikan masyarakat sangat berpengaruh dalam pembentukan desa yang baik. Pada lain sisi kondisi heterogenitas masyarakat turut memberikan motivasi bagi pengembangan desa dalam menciptakan berbagai program-program pengembangan desa yang berkualitas bagi masyarakatnya. Dengan posisi di Kota Ambon yang dekat dengan Desa Latta sudah barang tentu arus mobilisasi penduduk cukup tinggi dan membutuhkan kesiapan desa dalam menyediakan berbagai infrastruktur pengembangan ekonomi yang baik dan berguna.

Di desa Latta terdapat 3 jenjang pendidikan yaitu 3 SD, 1 SMP, 1 SMA, oleh karena itu dapat dikatakan tingkat pendidikan desa ini cukup baik.

Selain itu dilihat dari jenis pekerjaan maka sebagian besar masya-rakat Desa Latta bekerja sebagai pegawai negeri. Disamping itu juga ada yang bekerja sebagai pensiun, TNI/POLRI, Wiraswasta, nelayan dan lain-lain. Dari komposisi pekerjaan warga maka, diperkirakan pendapatan perbulan dapat dirinci sebagai berikut :

a. Nelayan : Rp. 100.000-400.000 bahkan lebih jika ada musim panen hasil laut maupun hasil laut

b. Pegawai Rp. 1.000 .000 ke atas dilihat dari golongan dan masa kerja.

c. Honor daerah dan honor sekolah disesuaikan

d. Pensiun disesuaikan

e. Wiraswasta : Rp. 150.000-300.000 bahkan lebih jika panen hasil

f. Pertukangan disesuaikan.

Selanjutnya dilihat berdasar-kan agama dimana masyarakat Desa Latta ada 3 agama yaitu agama Kristen Protestan, Kristen Katolik dan Islam.

\section{Latta Ditengah Realitas Konflik}

Terjadinya konflik antar sau-dara di Maluku telah menghadirkan perubahan pada tatanan kehidupan sosial masyarakat. Kehidupan ber-sama antara masyarakat Islam dan Kristen bagaikan barang antik yang sangat susah ditemukan. Hubungan antara keduanya semakin jauh ka-rena masing-masing hidup sendiri-sendiri. Kondisi ini rupanya selaras dengan pernyataan Pieter Tanamal (1987:7) bahwa: relasi antar orang dalam masyarakat juga menjadi renggang, malah nampak tertutup secara sengaja.
Walaupun sebagian masyarakat telah terkondisi seperti itu, tidak demikian halnya bagi masyarakat desa Latta. Sepanjang terjadinya konflik, masyarakat tetap hidup menyatu dan mempertahankan tata-nan kehidupan bersama antara Islam dan Kristen yang telah dibina sejak awal. Relasi-relasi atau hubungan-hubungan sosial tetap terjalin dengan baik antara satu dengan lainnya. Realitas kehidupan yang diperlihatkan ternyata selaras de-ngan pemikiran Peter L Berger (1974:36) yang menyatakan bahwa: apapun perbedaan yang terdapat diantara berbagai sektor kehidupan sosial, mereka tetap 'bersatu' dalam sebuah tatanan yang mengintegrasikan makna keseluruhan masyarakat tersebut. Tatanan tersebut bersifat religius. Bagi individu, tatanan tersebut tidak lain adalah simbolsimbol integratif yang sama, yang meresap ke dalam berbagai sektor kehidupan sehari-hari.

Berbagai persoalan dan konflik yang terjadi di Maluku belum dapat menggoyahkan kehidupan bersama antara masyarakat Islam dan Kristen di Latta, hubungan-hubungan sosial yang terbangun bahkan kerja sama dan saling menghormati antara satu dengan lainnya berjalan dengan baik di antara dua komunitas yang berbeda. Bahkan, pe-ristiwa atau konflik yang terjadi dise-keliling Latta tidak dapat mem-pengaruhi masyarakat Latta. Tidak dapat disangkal bahwa ketahanan diri masyarakat setempat perlu diacungi jempol dan patut dicontohi dalam upaya rekonsiliasi damai secara menyeluruh di Maluku, bahkan dapat dijadikan tolak ukur hidup persaudaraan antar pemeluk agama di Indonesia.

Ketahanan masyarakat dilatar belakangi oleh berbagai hal yang terwujud dalam praktek kehidupan sehari-hari. Dari sisi kehidupan politik, warga masyarakat benar-benar memahami keberadaannya sebagai warga negara yang sama, bahkan dalam segala sesuatu selalu mengedepankan ciri ke Indonesiaan terma-suk dalam pemerintahan desa. Dilain sisi, ketahanan masyarakat juga terjaga karena mereka memiliki tingkat pendidikan yang baik. Wawasan berpikir masyarakat cukup baik dalam menganalisa setiap situasi yang berkembang. Selain itu, tingkat ekonomi masya-rakat yang cukup memadai membuat mereka tidak terpancing untuk terlibat dalam tindakan-tindakan yang tidak benar.

Dapat dikatakan bahwa keadaan Desa Latta yang masih aman merupakan usaha semua warganya, baik Islam maupun Kristen. Penanganan secara cepat dan akurat dari berbagai pihak yang paling bertanggung jawab atas warganya seperti 
Kepala Desa, Pendeta, Imam dan aparat militer yang berhasil meredakan ketegangan-ketegangan yang terjadi di kalangan masyarakat sehingga kelangsungan hidup kebersamaan masih tetap terpelihara. Untuk hal ini, Pieter Tanamal (1985:31) mengatakan bahwa: dalam persengketahan antar negeri di Maluku yang sering sekali terjadi, penyelesaian persoalannya terletak pada para pemimpin di dalam negeri.

Ada beberapa cara yang dilakukan pemerintah dan masyarakat desa Latta untuk tetap menjaga dan melestarikan nilai-nilai persaudaraan dalam kehidupan masyarakat Islam dan Kristen yaitu:

1. Saling menghormati dan menghargai satu dengan yang lain atau antar agama dengan dilandasi pengertian yang baik.

2. Berusaha berpikir baik terhadap orang lain dan bertindak sesuai dengan pemikiran itu, menganggap semua yang terjadi (konflik Maluku) sebagai realita yang harus dijalani sehingga tidak memberikan peluang untuk membalas dendam.

3. Kembali kepada hidup yang sesungguhnya yang beradab dan sesuai dengan budaya dan ajaran agama.

4. Hentikan konflik yang sia-sia dan buanglah dendam yang ber-semayang di dasar hati.

5. Tumbuh dan kembangkan lagi nilai-nilai budaya dengan kesa-daran yang utuh.

6. Perlu adanya saling kerja sama dan saling pengertian.

7. Menciptakan kerukunan antar umat beragama.

8. Perlu adanya sosialisasi nilai dan norma persaudaraan Islam Kristen ke semua lapisan masyarakat.

Ketika nilai-nilai persaudaraan Islam Kristen dapat diilhami dengan benar dalam kehidupan masyarakat desa Latta maka upaya ini dapat membantu rekonsiliasi damai di Maluku secara menyeluruh karena didalamnya telah terintegrasi nilai-nilai perdamaian dan cinta kasih yang hakiki.

\section{Interaksi Sosial Antar Masya-rakat di Desa Latta}

Kontak sosial dan komunikasi sosial dalam pola pembinaan dan pengembangan kehidupan bermasyarakat di Desa Latta Kecamatan Teluk Ambon Baguala Kota Ambon dilakukan dalam pendekatanpendekatan sosial yang bernuansa kepada budaya dan kerukunan antara masyarakat. Pola kebersamaan dan keikutsertaan berbagai stackholder masyarakat dalam kehidupan bermasyarakat dilakukan dengan menata pola-pola kehidupan sosial dan budaya masyarakat di desa Latta. Pola lain yang terjadi di Desa Latta adalah adanya ruang yang besar terhadap proses untuk saling bertukar pikiran dan pendapat, baik dalam memecahkan masalah maupun dalam hal pengembangan desa dan masyarakat. Menurut informan kunci dalam hidup hari-hari (baik Islam maupun Kristen) adanya sikap saling bertukar pikiran atau pendapat juga hidup saling membu-tuhkan satu dengan yang lain dan saling memberikan apa yang ada baik secara pribadi, keluarga, kelompok maupun masyarakat selalu terjadi dalam masyarakat. Pendapat lain juga yang disampaikan oleh informan yaitu pengembangan kehidupan bermas-yarakat dan bersosial di desa Latta adalah menunjukkan adanya saling ketergantungan dan keharmonisan. Hal itu dapat diciptakan hanya dengan saling menerima dan mengakui berbagai kelemahan dan kekurangan masing-masing individu. Selain itu adanya gerakan dari pe-merintah Desa untuk memanggil pulang seluruh masyarakat desa Latta yang mengungsi karena faktor kerusuhan Maluku yang terjadi dan memberikan jaminan keamanan dan kondisi sosial yang baik bagi mereka untuk dapat bersama-sama membangun kembali desa Latta agar menjadi lebih baik, sehingga dalam waktu 4-5 tahun ini Desa Latta dapat tumbuh dan berkembangan menjadi desa yang majemuk dengan tingkat pemahaman dan kepedulian sosial yang sangat tinggi.

Hubungan kekerabatan antara budaya dan suku di desa Latta dapat dikatakan sangat baik, ini tergambar jelas dalam proses pembangunan infrastruktur masyarakat seperti membangun Masjid yang rusak. Masjid dibangun bersama-sama dengan suku dan golongan agama lainnya. Hal ini menunjukkan bahwa masyarakat sangat memahami akan nilai-nilai kerukunanan dalam kehidupan bermasyarakat.

\section{Modal Sosial}

\section{- Trust (Saling Percaya)}

Meskipun potensi konflik ada di dalam masyarakat dan antar negeri yang bertetangga, dan bahkan konflik cukup sering mewarnai dina-mika masyarakat di Desa Latta, tetapi rasa saling percaya pada umumnya dapat dikatakan masih terpelihara baik pada tingkatan individu, kelompok maupun antar negeri bertetangga. Potensi saling percaya (social trust) diketahui cukup besar, mengingat homogenitas masyarakat terutama dari segi agama (bonding social capital). Indikasi ini terlihat dari pernyataan para informan yang mengatakan bahwa 
semua orang yang hidup di Desa Latta ini adalah orang basudara (bersaudara).

Kondisi di atas tercermin dari relasi-relasi sosial dalam keseharian interaksi antar warga di dalam desa, khususnya beberapa aktivitas sosial tertentu seperti misalnya:

a) Saling bantu-membantu dalam membangun rumah baik itu rumah-rumah ibadah maupun rumah penduduk. Bantuan yang diberikan tidak dipungut biaya atau balasan apapun. Mereka saling membantu ka-rena ada rasa katong orang basudara.

b) Sikap saling menghargai terbangun dalam masyarakat. Hal ini terlihat ketika proses ibadah kedua komunitas ini saling menjaga ketertraman dan kedamaian.

c) Interaksi antar tetangga dan warga desa pada umumnya berlangsung lancar. Semua masalah yang pernah terjadi, bisa diselesaikan dengan baik.

\section{- Jejaring}

Warga masyarakat Latta umumnya menjadi anggota dari lebih satu asosiasi yang ada di dalam desanya, baik organisasi yang terkait dengan aktivitas ekonomi maupun organisasi gerejawi seperti keanggotaan dalam Wadah Pelayanan Pria, Wadah Pelayanan Wanita, Unit, Sektor, Angkatan Muda Gereja Protestan Maluku, dan sebagainya.

Kondisi di atas menyebabkan intensitas interaksi di antara sesama warga cukup tinggi, karena berbagai kegiatan gerejawi yang bersifat ibadah, hampir dilakukan setiap hari. Pertemuan yang sangat sering ini menyebabkan tingkat kohesi sosial pun cukup tinggi dan mampu menjamin stabilitas sosial serta keamanan di dalam desa.

Dalam setiap kesempatan pertemuan, menurut informan kunci, masyarakat memanfaatkannya untuk membahas berbagai masalah aktual yang terjadi di dalam desa.

\section{Simpulan}

Bertolak dari keseluruhan pembahasan, maka ada beberapa hal yang dapat penulis simpulkan yaitu: hubungan interaksi merupakan salah satu hal yang sangat penting dalam kehidupan beragama. Kehidupan yang harmonis dapat berjalan dengan baik apabila wujud nyata dari interaksi itu benarbenar terbangun. Konflik yang terjadi dalam masyarakat diakibatkan karena hubungan interaksi yang kurang baik antar satu dengan lainnya.
Persaudaraan antara masyarakat Islam dan Kristen merupakan budaya warisan leluhur yang kandungan nilainya tidak bertentangan dengan ajaran agama. Hubu-ngan persaudaraan ini merupakan salah satu wujud budaya yang mengintegrasikan pola hidup masyarakat Maluku yang berbeda agama yang berfungsi sebagai alat pemersatu dalam masyarakat.

Masyarakat desa Latta merupakan salah satu masyarakat di kota Ambon yang mampu memelihara nilai-nilai persaudaraan antar agama. Meskipun masyarakat desa Latta ada dalam berbagai perbedaan baik itu perbedaan agama dan budaya namun mereka tetap menjalin hubungan interaksi dan komunikasi yang baik antar satu dengan lainnya.

Sebelum dan sesudah pasca konflik hubungan interaksi itu tetap terjalin. Mereka tidak mudah terpro-vokasi dengan isu-isu yang beredar dalam masyarakat. Masyarakat benar-benar menjaga kehidupan persaudaraan antar umat beragama yaitu Islam Kristen sambil berserah pada Tuhan dan berusaha memelihara sesuai dengan apa yang diajarkan oleh agama baik Kristen maupun Islam.

\section{Ucapan Terima Kasih}

Pada kesempatan ini, penulis mengucapkan terima kasih kepada para responden yang telah bersedia menjadi objek penelitian bagi penulis. Terima kasih juga kepada Redaktur yang telah memberikan masukan yang berharga sehingga tulisan ini dapat disajikan di Jurnal Institutio, Terima kasih yang sama juga kami ucapkan kepada pengurus Jurnal Institutio yang telah memberi ruang diskusi

Semua bantuan dalam bentuk apapun yang diberikan kepada penulis, tidak dapat penulis balas satu persatu-satu, hanya doa semoga kita semua dapat senantiasa dalam lindungan Tuhan.

\section{Pustaka Acuan}

Charles H Cooley, 1930, Sociological Theory and Social Research, New York : Henry Holt and Company

Durkheim Emille, 1964, The Rules Of Sociological Method, translated by Sarah A. Solovay and John H. Mueller and edited by Gearge E.G. Catlin, New York: Free Press. 
Gillin dan Gillin, 1954, Cultural sociology, a revision of an intriduction to sociology, New York: The Macmillan.

Husaini Usman dan Purnomo Setiady akbar,2000, Metodologi Penelitian Sosial, Jakarta: Bumi Aksara.

Kimball Young dan Raymond, W Mack, 1959, Sociologi and Social Life, New York : American Book Company.

Lauer H. Robert, 2003. Persfektif Tentang Perubahan Sosial. Jakarta: Rineka Cipta.

Macionis J. Jhon, Sociology. London Prentice-Hall International,Inc.

Manuael Castells, 2003, The Power of Identity, Vol II, Blackwell Publishing, USA.

Moleong Lexy, 2000, Metodologi Penelitian Kualitatif, Bandung, Remaja Rosdakarya.

Ross dan Gloria Kinsler, The Biblikal Lubilee and the Struggle For Live, Berkley, California Press

Slamet Santoso, 2010, Teori-Teori Psikologi Sosial, Bandung: PT Refika Aditama

Soekanto Soerjono, 2004, Sosiologi Suatu Pengantar, Jakarta: Raja Grafindo Persada

Sztompka Piotr, 2007, Sosiologi Perubahan Sosial, Jakarta: Prenada

Tanamal Pieter, 1985, Pengabdian dan Perjuangan, Ambon: Offset PNRI Ambon 